\title{
THE COMBINED ACTION OF PENTOBARBITAL AND MEPERIDINE, AND OF PROCAINE AND MEPERIDINE, IN GUINEA PIGS ${ }^{1}$
}

\author{
Madizlaine O. Maykut, PH D. ${ }^{2}$
}

Several aUthors $(1,2,3,4,5)$ have noted that meperidine reduces the amount of barbiturate required to produce adequate narcosis. It is known that morphine, to which meperidine is distantly related, prolongs the depressant action of barbiturates $(6,7,8,9)$. Recently a profound respiratory depression was reported with thiopental when premedication with morphine or meperidine was given (10) "This respiratory depression had been reported earlier (11), but the degree of depression was not considered serious at the time since it was compared with that occurring with methadone.

On the other hand, reports have appeared $(12,13)$ indicating that meperidine possesses local anaesthetic action preceded by preliminary irritation. It was therefore of interest to see whether meperidine would augment the action of procaine and whether the combined effect of meperidme and pentobarbital had both antagonistic and synergistic trends, as was previously found with procaine and pentobarbital (14).

\section{Materials and Methods}

The substances used were Nembutal ${ }^{\circledR}$ (pentobarbital sodium), Demerol ${ }^{\circledR}$ (meperıdıne hydrochloride), and procaine hydrochloride (Novocaine ${ }^{\circledR}$ ).

The experimental animals were white guinea pigs. Injections were made in areas where the hair was clipped and, when only one drug was injected, physiological saline replaced the injection of the second drus. The first of a series of experiments, during which each animal was closely o sserved, was designed to survey qualitatively the effects of the combination of two drugs. The most conspicuous and consistent symptoms were subsequently trạnslated into symbols. From such a survey dosages of the two drugs could be chosen to give graded responses which could then be analysed.

The acute toxicities of the drugs, admmistered by intramuscular or subcutaneous injection, alone and in combination, were determined; all animals died within the 24-hour perıo. The LD50's (lethal dose) and their standard errors were estumated as described by Finney (15)

\section{Pentobarbital and Meperidine}

The average body weight of the guinea pigs was $624 \mathrm{gm}$. with a standard deviation of $144 \mathrm{gm}$.

Pentobarbital 2 per cent solution was injected in divided doses intramuscularly into the hind limbs of the animals, after which an injection of 4 per cent meperidine solution in divided doses was made intramuscularly into the fore limbs of

1The data included herein were taken partly from a Thesis submitted in partal fulfilment of the requirements for the degree of Doctor of Philosophy, University of Toronto, May, 1957.

2Department of Pharmacology, University of Toronto. 
the animals. Sleeping times indicated by the absence of the righting reflex were measured using ten animals at each dose level The same animals were used only once a week since it had been reported $(16,17,18,19,20,21)$ that tolerance results in decreased sleeping time after the first few daily injections of pentobarbital.

\section{Procaine and Meperidine}

The guinea pigs used had an average body weight of $537 \mathrm{gm}$. with a standard deviation of $180 \mathrm{gm}$.

A 4 per cent solution of meperidine was injected in divided doses intramuscularly into the hind limbs of the animals following which 10 per cent procaine was injected subcutaneously on both sides of the back of the guinea pig.

Since convulsions produced by meperidine and procaine were intermittent and not continuous, it was decided that it would not be possible to use the duration of convulsive state as an index of action; instead it was decided to determine merely the CD50, that is, the dose required to produce convulsions. A total of 178 animals was used in these experiments, the number at each dose level ranging from 10 to 35 guinea pigs because the convulsive response obtained was irregular.

\section{Results}

\section{Pentobarbital and Meperidine}

Pentobarbital alone gave rise to sleep; meperidine alone produced convulsions.

The hypnotic action of the combined drugs was investigated, and the results are presented in Table $I$ and in a three-dimensional diagram (Fig. 1a); this diagram is similar to that presented in a previous report on procaine and pentobarbital (14). The axes indicate concentrations of pentoburbital (N) and meperidine (D) expressed in logarithms, the height of the diagram representing the average duration of sleep in minutes. The lowest combination $\mathrm{N}_{1} \mathrm{D}_{1}$ represents 65 minutes and the highest $\mathrm{N}_{3} \mathrm{D}_{3} 563$ minutes. While the duration of sleep obtained with pentobarbital and meperidine increases with increasing concentrations of meperidine for all doses of pentobarbital, it should be noted that the concentration of meperidine must be increased considerably to bring about. any, change (Fig. la).

The data were subjected to statistical analysis using the logarithm of response. The $\chi^{2}$ test for over-all homogeneity of variance, athough slightly significant, did not vary significantly and the variance does not change with increasing doses

TABLE I

Duration of SLeEping Time IN Minutes following MePeridine and Pentobarbital

\begin{tabular}{crrr}
\hline \multirow{2}{*}{$\begin{array}{c}\text { Dose of Meperidine } \\
\text { (mg / kg ) }\end{array}$} & \multicolumn{3}{c}{ Dose of pentobarbital (mg / kg ) } \\
\cline { 2 - 4 } & 15 & 212 & 30 \\
\hline 2 & 653 & 1266 & 1901 \\
18 & 1248 & 1757 & 2704 \\
162 & 2014 & $326 \mathrm{6}$ & 5634 \\
\hline
\end{tabular}


of either drug. It seemed reasonable, therefore, to calculate the results using the logarithm of the response since the data would be presented in a more straightforward fashion and the curved surface approaches a plane when the log response is used (Fig. $1 \mathrm{~b}$ ). The increase in sleeping time with increase in pentobarbital $\left(N_{1}\right.$ to $\left.N_{3}\right)$ and meperidine $\left(D_{1}\right.$ to $\left.D_{3}\right)$ is statistically significant. The slopes of the lines for increasing pentobarbital dose effects at each meperidine dose level are

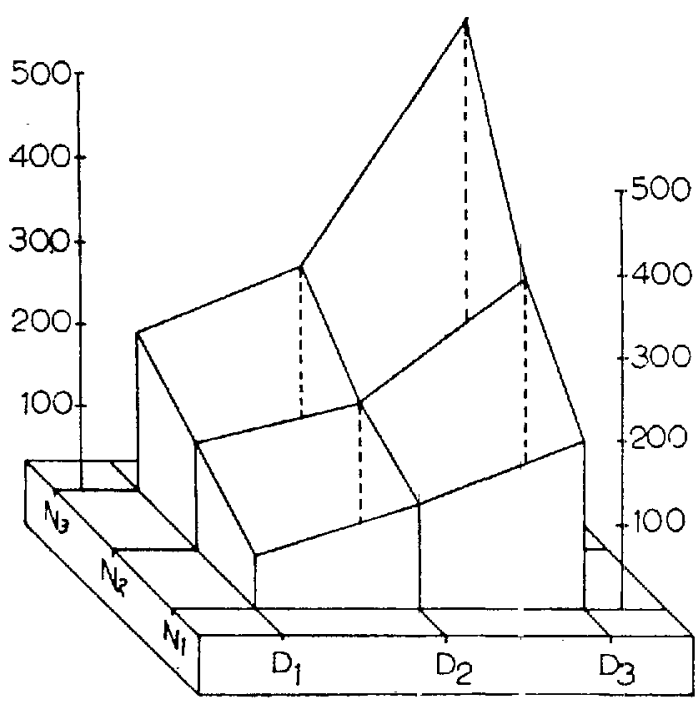

(a)

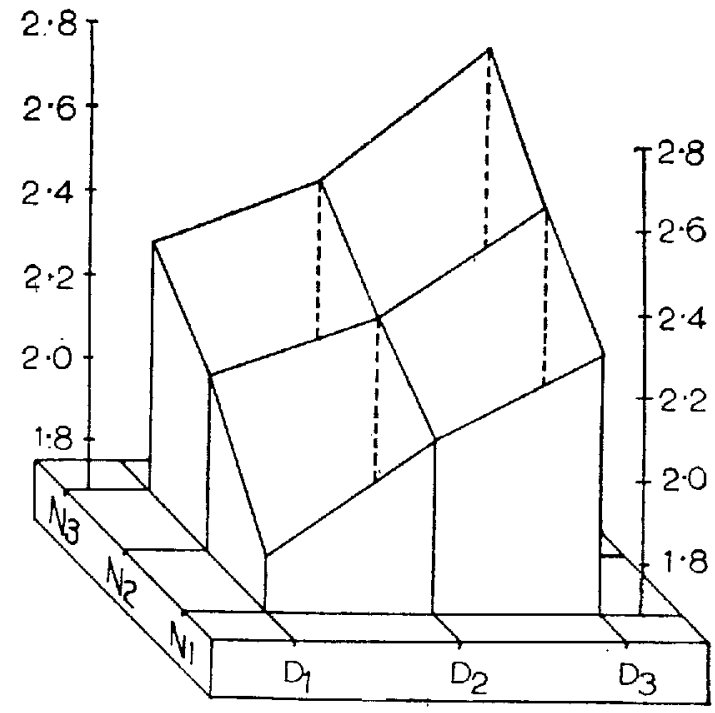

(b)

Figure 1. Hypnotic action of combinations of meperidine and pentobarbital in guinea pigs. The two horizontal axes represent increasing doses of the two drugs in logarithms; $D$ stands for meperidine, $\mathrm{N}$ for pentobarbital: $(a)$ the vertical axis represents sleeping time in min. $(b)$ the vertical axis represents sleeping time in log min.

similar; the same is true for increasing meperidine dose effects at each pentobarbital dose level. Since the slopes are quite similar, interaction does not occur as is indicated in the analysis. On the basis of this statistical analysis the surface may be interpreted as a simple plane since no deviation from linearity occurs and the slopes are the same.

Table II lists the figures obtained for the acute toxicities of pentobarbital and meperidine, alone and in combination. The effect of meperidine on the LD50 of pentobarbital, as well as that of pentobarbital on the LD50 of meperidine is

TABLE II

Acute Toxicities of Pentobarbital and Meperidine(intramuscular) Alone AND in COMBinatron

\begin{tabular}{|c|c|c|c|c|}
\hline & $\begin{array}{r}\mathrm{LD} 50 \\
\mathrm{mg} \\
\end{array}$ & $\begin{array}{l} \pm \text { S.E. } \\
\text { /kg. }\end{array}$ & Slope* & $\begin{array}{l}\text { Number of } \\
\text { guinea pigs }\end{array}$ \\
\hline Pentobarbital & 70.3 & \pm 4.7 & 7.9 & 35 \\
\hline $\begin{array}{l}\text { Pentobarbital } \\
+35 \text { mg. } / \mathrm{kg} \text {. meperidine } \\
\text { Meperidine }\end{array}$ & $\begin{array}{r}46.5 \\
111.0\end{array}$ & $\begin{array}{l} \pm 6.5 \\
\pm 14.0\end{array}$ & $\begin{array}{l}7.1 \\
9.2\end{array}$ & $\begin{array}{l}40 \\
30\end{array}$ \\
\hline $\begin{array}{l}\text { Meperidine } \\
\quad \pm 10 \mathrm{mg} . / \mathrm{kg} \text {. pentobarbital }\end{array}$ & 315.0 & \pm 22.0 & 14.6 & 40 \\
\hline
\end{tabular}

*Probit units per log dose. 
significant. In the presence of meperidine ( $35 \mathrm{mg} . / \mathrm{kg}$. which is less than LDl) the LD50 of pentabarbital is decreased to $46.5 \mathrm{mg} . / \mathrm{kg}$. This amount of pentobarbital when used alone is equivalent to LD4. The toxicity of meperidene is decreased by pentobarbital, the LD50 being raised from $111 \mathrm{mg} . / \mathrm{kg}$. to $315 \mathrm{mg} . / \mathrm{kg}$. The latter amount of meperidine alone is equivalent to LD92.

\section{Procaine and Meperidine}

The symptoms noted, excitement, tenseness, unsteadiness, convulsions, resulting from the administration of various concentrations of meperidine and procaine, are shown in Figure 2. Attention is directed to the observations that the combination of meperidine and procaine is more toxic than either drug alone in similar dosage.

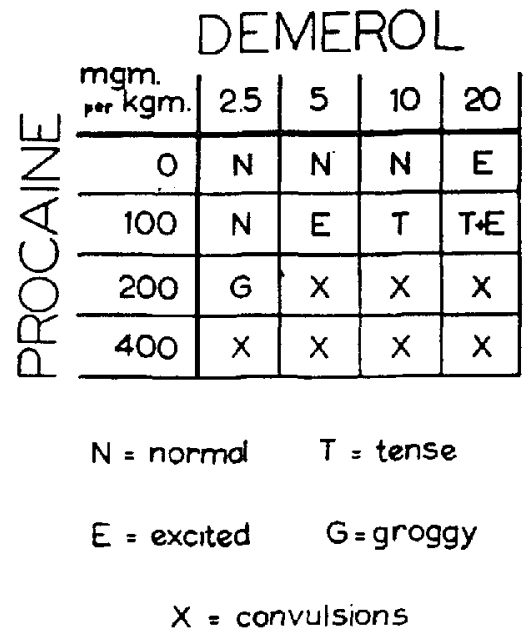

Figure 2. Symptoms of individual guinea pigs given various dose combinations of meperidine (Demerol) and procaine.

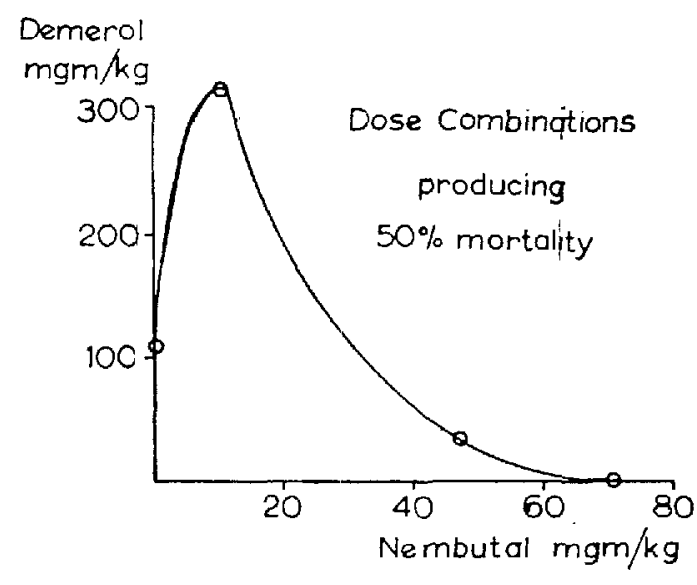

FIGURE 3. Lethal action of meperidine (Demerol) a ad pentobarbital (Nembutal), alone and in combination, in guinea pigs.

The values obtained for the CD50 of meperidine and of procaine are shown in Table III. When one-half the CD50 of both drugs was injected, the combined effect resembled potentiation; it was expected that $41.5 \mathrm{mg} . / \mathrm{kg}$. meperidine and $90.5 \mathrm{mg} . / \mathrm{kg}$. procaine injected into 40 animals would give a 50 per cent response but an 87.5 per cent response was observed.

The results obtained by combining procaine and meperidine in various doses are indicated in Table IV. This table shows that an increase in percentage of convulsions occurs with increasing procaine doses at all meperidine dose levels and a similar increase occurs with increasing meperidine doses at all procaine levels, but an erratic trend can be noted at the $9.0 \mathrm{mg} . / \mathrm{kg}$. meperidine level.

TABLE III

Convulsive Dose 50 of Meperidine and Procaine Alone

\begin{tabular}{|c|c|c|c|c|}
\hline & $\begin{array}{r}\text { CD50 } \\
\text { (mg }\end{array}$ & $\begin{array}{l} \pm \mathrm{S} . \mathrm{E} . \\
\text { (kg.) }\end{array}$ & Slope & $\begin{array}{l}\text { Number of } \\
\text { guinea pigs }\end{array}$ \\
\hline $\begin{array}{l}\text { Meperidine (intramuscular) } \\
\text { Procaine (subcutaneous) }\end{array}$ & $\begin{array}{r}83.1 \\
180.9\end{array}$ & $\begin{array}{r} \pm 9.9 \\
\pm 28.0\end{array}$ & $\begin{array}{r}12.6 \\
6.8\end{array}$ & $\begin{array}{l}35 \\
40\end{array}$ \\
\hline
\end{tabular}


TABLE IV

Percentage of Convulsions in Guinea Pigs Following Meperidine AND PROCAINE

\begin{tabular}{lcccr}
\hline \multirow{2}{*}{$\begin{array}{c}\text { Dose of procaine } \\
(\mathrm{mg} / \mathrm{kg})\end{array}$} & \multicolumn{5}{c}{ Dose of meperidine $(\mathrm{mg} / \mathrm{kg})$} \\
\cline { 2 - 5 } & 45 & 65 & 90 & 125 \\
\hline 104 & 20 & 40 & 36 & 40 \\
125 & 35 & 50 & 50 & 72 \\
150 & 70 & 80 & 61 & 100 \\
\hline $\mathrm{CD} 50$ & 1345 & 1190 & 1266 & 1101 \\
$\pm \mathrm{SE}$ & 175 & 179 & 215 & 88 \\
\hline
\end{tabular}

In Table $\mathrm{V}$ are recorded the values obtained for the acute toxicities of procaine and meperidine, alone and in combination The effect of procaine on the LD50 of meperidine, as well as that of meperidine on the LD50 of procaine, is not significant, meperidine $90 \mathrm{mg} . / \mathrm{kg}$ represents LD42 and procaine $402 \mathrm{mg} / \mathrm{kg}$., LD45:

TABLE V

Acute Toxicities of Meperidine and Procaine Alone and in Combination

\begin{tabular}{|c|c|c|c|c|}
\hline & $\begin{array}{r}\text { LD50 } \\
\quad(\mathrm{mg}\end{array}$ & $\begin{array}{l} \pm S E \\
/ \mathrm{kg})\end{array}$ & Slope* & $\begin{array}{l}\text { Number of } \\
\text { guinea pigs }\end{array}$ \\
\hline $\begin{array}{l}\text { Meperıdinet } \\
\text { Meperidine }\end{array}$ & 111 & \pm 14 & 92 & 30 \\
\hline $\begin{array}{l}+300 \mathrm{mg} / \mathrm{kg} \text { procaine } \\
\text { Procanet } \\
\text { Procanne }\end{array}$ & $\begin{array}{r}90 \\
438\end{array}$ & $\begin{array}{r} \pm 5 \\
\pm 23\end{array}$ & $\begin{array}{l}117 \\
104\end{array}$ & $\begin{array}{l}30 \\
30\end{array}$ \\
\hline $\pm 35 \mathrm{mg} / \mathrm{kg}$ meperıdıne & 402 & \pm 76 & 54 & 40 \\
\hline
\end{tabular}

*Probit units per log dose

† Meperidine given intramuscularly, procame subcutaneously

\section{Discussion}

\section{Pentobarbital and Meperidine}

The results obtained are similar to those previously reported for pentobarbital and procaine (14). That is, meperidine like procame, increases the toxicity of pentobarbital. Further, pentobarbital appears to antagonize the effects of meperndine since the LD50 of meperidine is raised in the presence of pentobarbital. These double effects are represented graphically in Figure 3. In such a plot a strictly additive effect of the two drugs would be characterized by points lying on a straight line joining the.LD50 of meperidine and the LD50 of pentobarbital (22). The hump in the curve represents the antagonistic effect of pentobarbital and meperidine; the lower part of the curve indicates that the central depressant action of meperidine is very nearly additive to that of pentobarbital. From this it could be argued that a patient under the toxic influence of meperidine might be saved by the administration of pentobarbital, whereas in a case of barbiturate poisoning an additional injection of meperidine might prove fatal. Furthermore, these investigations emphasize that meperidine has two independent actions on the central nervous system; one is the production of convulsions, and this effect 
is counteracted by pentobarbital; the second action is a depressant one and augments the action of pentobarbital. Isonicotinic acid hydrazide (INA) and some related compounds appear to have similar actions to procaine and meperidine when combined with pentobarbital (23). That is, pentobarbital action is prolonged by these compounds, and it antagonizes the stimulant action of INA on the central nervous system. Other drugs which have been reported to enhance the action of barbiturates are benadryl (24), thiambutene (25), 5-hydroxy tryptamine $(26,27)$, sulfonamides and derivatives $(28,29,30)$, disulfiram (31), antihistamine (32), chlorpromazine (33), SKF 525A (34, 35), reserpine (36), and serotonin (37).

Acute toxicity studies of meperidine have been conducted in many species such as the mouse, rat, rabbit, cat, and dog, using various routes of administration (38). The present data cannot be compared since results were obtained on guinea pigs using the intramuscular route. However, the symptoms of excitement and convulsions observed were similar (39).

\section{Procaine and Meperidine}

The toxicities for both drugs, procaine and meperidine, were increased by using them in combination, as may be seen from the graphical presentation of the results (Figs. 4 and 5). The contours of the curves indicate that the convulsive effects of the two drugs combined are more than additive, whereas the lethal effects of the drugs are less than additive.

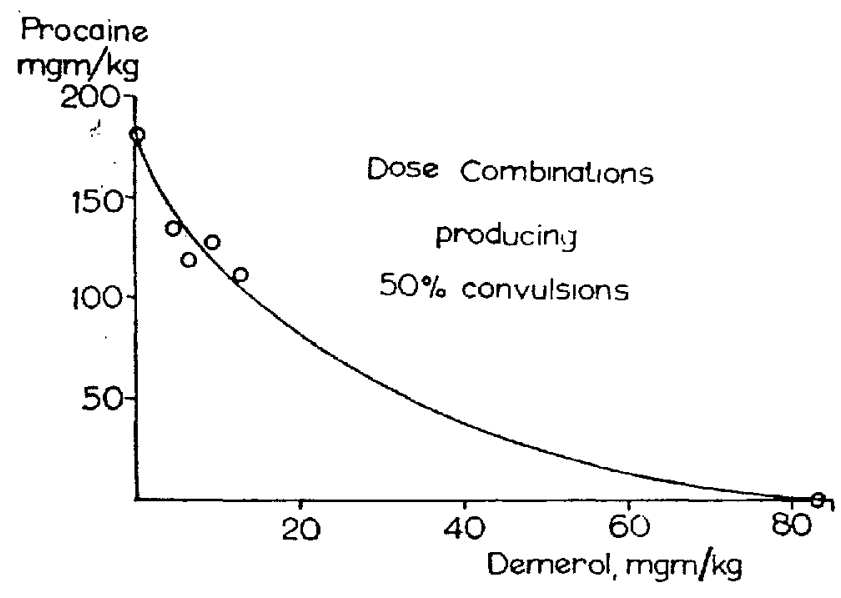

Figure 4. Convulsive action of meperidine (Demerol) and procaine, alone and in combination, in guinea pigs.
Dose Combinations

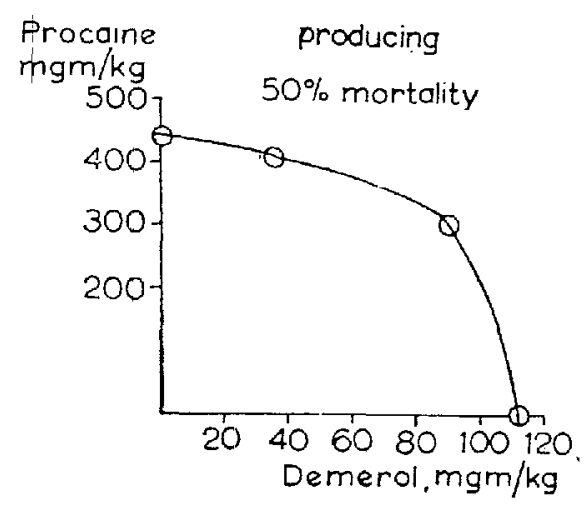

FiguRe 5. Lethal action of meperidine (Demerol) and procaine, alone and in combination, in guinea pigs.

Both drugs, meperidine and procaine, produce convulsions but the mechanisms responsible for this action may be different, since the slopes obtained for the CD50 of the drugs are different (Table III). However, the drugs combined produce additive effects. Also the slopes obtained for the CD50 (Table III) and the LD50 (Table V) of procaine as well as of meperidine are different, which may indicate that the mechanism of action giving rise to convulsions differs from that 
causing death. Similar potentiation phenomena hve been reported (40) where the analgesic effect of some drugs increases with the simultaneous administration of local anaesthetics and a synergism of acute toxicity occurs when quinidine, meperidine, and procaine are used in combination (41).

\section{SUMMARY}

Mependme increases the sleeping time induced by pentobarbital in guinea pigs

The effect of pentobarbital on the toxicity of meperidine was antagonistıc, whereas the effect of meperıdine on the toxicity of pentobarbital was nearly additive.

The results of these experiments show that pentobarbital will protect exper1mental animals against the convulsive effects of meperidine and that the depressant action of pentobarbital is augmented by the presence of meperidine It has been pointed out that when meperidine and procaine are combined there is a potentiation of convulsive effects, but their combined lethal effects, while greater than that of either one alone, are not additıve.

\section{ACKNOWLEDGMENTS}

Thanks are due to Dr. E E. Shouldice of Shouldice Surgery, Toronto, who observed the depressant actions of these drugs in man, and who initiated and financed this investigation; and to Professor H. Cullumbine, Professor G H W Lucas, and Dr. W. Kalow of the Department of Pharmacology, University of Toronto, for their interest and stimulating criticism. I am indebted to Professor D. B W. Reid of the Department of Epidemology and Biometrics, for his effort to analyse an unusual statistical problem

\section{RÉSUMÉ}

Des résultats expérımentaux ont laissé croire que la meperidıne (Demerol ${ }^{\circledR}$ ) avart un certain pouvoir comme anesthésıque local et qu'elle pourrait diminuer également la quantité de barbiturique requise pour produire une narcose satisfaisante Il nous a donc paru intéressant de vérufier si la meperidine n'augmenterait pas l'action de la procaine (un anesthésique local) et de vérifier également si l'effet associé de la meperidine et du pentobarbital (un barbiturique) ne présenterait pas des tendances à la fois antagoniste et synergique comme on l'avait découvert au préalable pour la procame et le pentobarbital.

Chez les cobayes, l'expérience a démontré que la meperidine augmente la durée du sommeil provoqué par le pentobarbital. Nous avons déterminé les doses toxiques (LD50) de ces médicaments employés seuls ou associés. Sur la toxicité de la meperidine, la pentobarbital s'est révélé un antagoniste et, sur la toxicité du pentobarbital, la meperidine a semblé avoir un effet presqu 'additionnel. Les résultats de l'expérience font croire que le pentobarbital peut protéger les animaux contre les effets convulsivants de la meperidine et que cette même meperidine augmente l'action déprimante du pentobarbital 
Si l'on associe la meperidine et la procame, il se produit une potentialisation de leurs effets convulsivants mais leurs doses léthales associées ne s'additionnent pas bien qu'elles soient plus grandes que l'une ou l'autre seule. Les mécanismes en jeu à l'occasion de convulsions peuvent être différents puisque les courbes obtenues pour les doses convulsivantes de ces médicaments 50 (CD50) sont différentes. Ainsi, les courbes obtenues pour le CD50 et le LD50 de l'un ou l'autre des médicaments, sont différentes, ce qui peut laisser croire que le mécanisme qui entre en jeu à l'occasion de convulsions est différent de celui qui cause la mort.

\section{REFERENCES}

I Barlow, D W, Climenko, D R, \& Homburger, E. Comparative Potentiating Effects of Certain Therapeutic Agents on Sodium Evipal Hypnosis. Proc Soc. Exper. Biol \& Med 49. 11 (1942)

2 Rovenstein, E A, \& Batterman, R C The Utility of Demerol as a Substatute for the Opiates in Pre-anaesthetic Medication Anesthesiology 4. 126 (1943).

3 Stephen, C. R, \& Pasquet, A Anesthesia for Neurosurgical Procedures. Analysis of 1000 Cases Anesth \& Analg 28: 77 (1949).

4 Randall, H. S, Belton, M. K, \& Leigh, M D Continuous Infusion of Demerol during Anaesthesia Canad M A.J 67: 311 (1952).

5 Glassman, J M., \& SetFrer, J. The Effects of Analgesic Agents on Barbiturate Responses in Mice J. Pharmacol Exper Therap 11521 (1955).

6 Lundy, J S Intravenous Anesthesia Particularly Hypnote Anesthesia and Toxic Effects of Certam New Denvatives of Barbituric Acid Anesth. \& Analg. 9. 210 (1930).

7. Rowbothaim, S. Premedication Brit M J 2. 693 (1931).

8. Seevers, M. H. Morphine Pentobarbital Anesthesia for Dog Surgery J Lab \& Clin. Med. $: 19202$ (1933)

9 Vogeler, K, \& Kotzoglu, P Administration of Morfhine before inducing Anesthesia by Sodum Evipan Internat Surg Digest 20. 18 (1935).

10 Helrich, M, Eckenhoff, J E, Jones, R E, \& Rolph, W D Influence of Opiates on the Respuratory Response of Man to Thiopental Anesthesiology 17. 459 (1956)

11 Luduena, F P, Miller, L C., Ananenko, E, \& Frick, J. D. Some Pharmacological Actions of Isomers of Methadon Federation Proc 7: 241 (1948).

12 WAY, E L Studies on the Local Anesthetıc Properties of Isonipecaine J Am Pharm A. 35: 44 (1946).

13 Everetr, F. G The Local Anesthetic Properties of Amidone (Dolophine) Anesthesiology 9: 115 (1948).

14 Maykut, M O, \& Kalow, W Experiments with Animals on the Combined Action of Procaine and Barbiturates Canad Anaesth Soc. J. 2. 109 (1955).

15. FinNey, D. J. In Burn, Biological Standardization, 2ad ed. London Oxford (1950)

16. Frrch, $R \mathbf{H}$ An Expenmental Study of Tolerance to Barbiturates. J Pharmacol \& Exper Therap. 39266 (1930).

17. Carmichael, E. B Observations on Effect of Repeated Administration of Nembutal in Guinea Pigs Proc Soc Exper Brol \& Med 30. 1329 (1933).

18 Carmarchael, E. B, \& Posex, L C Studres on the Toxicity and Tolerance of Nembutal in Gunea Pigs. J. Pharmacol \& Exper Therap 57116 (1936)

19. Extingen, G. H The Duration of Anaesthesia Produced in the Dog by the Repeated Administration of Dial and Nembutal J. Pharmacol \& Exper. Therap. 63 82 (1938).

20. Masuda, M, Budde, R. N., \& Dille, J. M. An Investigation of Acquired Tolerance tc Certain Short-Acting Barbiturates. J. Am. Pharm. A. 27: 830 (1938).

21. Kunsey, V E. The Use of Sodium Pentobarbital for Repeated Anesthesia in the Guinea Pig. J. Am Pharm A 29. 342 (1940) 
22 Gaddum, J. H. Pharmacology, 4th ed. London: Oxford (1953).

23 Goldin, A., Dennis, D.; Venditti, J. M.; \& Humphreys, S. R. Potentiation of Pentobarbital Anesthesia by Isoarcotinic Acid Hydrazide and Related Compounds Science 121. 364 (1955).

24 Sherman, J F. Enhancement of the Central Nervous System Effects of Strychnine and Pentobarbital by Diphenhydramine. Science 123: 1170 (1956).

25. Owen, L. N. Thiambutene and Barbiturate Anesthesia in the Dog J Pharm \& Pharmacol 7. $533(1955)$

26. Fornaroli, P, \& Koller, M Interaction betweèn 5-hydroxy-tryptamine and Narcotic Substances. Chem Abstr 50.6674a (1956):

27. Pierre, R, \& Cahn, J Essaus d'anesthésie prolongée par la 5-hydroxytryptamine Compt rend Soc. de Biol. 149: 1406 (1955).

28. Adriant, J. Effects of Aneșthetic Drugs upon Rats Treated with Sulfanilamide. J Lab \& Clin. Med. 24: 1066 (1939).

29 Butler, T C., Dickinson, H L, Govier, W M, Greer, C M, \& Lamison, P. D The Effect of Sulfanilamide and Some of Its Derivatives on the Reaction of Mice to Anesthetics. J Pharmacol \& Exper. Therap 72298 (1941)

30 Goldbaum, L R \& Hubbaind, T F Effects of Cannamide 14 'carboxyphenylmethane sulfonanilude) on the Metabolism of Thropental in Mice J Pharmacol. \& Exper. Therap 99366 (1950)

31. Graham, W D, Carmchate, E J., \& Allmark, M G The in vivo Potentiation of Barbiturates by Tetraethylthuram Disulphide J. Pharm \& Pharmacol 3: 497 (1951).

32 Lightstone, H, \& Neison, J. W Antihistamine Potentiation of Pentobarbital Anesthesia. J Am. Pharm. A 43263 (1954).

33 Dundee, J. W. A Review of Chhlorpromazine Hydrochlonde Fint J. Anaesth 26357 (1954).

34 Maxwell, J W, Cook, L', Davies, G J, Toner, J J, \& Fei,lows, E G Effects of Beta-dıethylaminoethyl-dıphenylpropylacetate Hydrochlonde (SKF No 525A) on a Series of Hypnotics Federation Proc 12349 (1953)

35 Achop, L B, \& GeIling, E M. K Effects of SKF Compound 525A on Excretion of Pentothal-S 35 in Mice. Proc Soc, Exper Biol \& Med 87: 261 (1954).

36 Brodie, B B, Shóre, P A, \& Shver, S. L Potentating Action of Chlorpromazine and Reserpine Nature 175 11:33 (1955)

37 Shore, P A, SiLver, S L, \& Bronie, B B Interaction of Serotonin and Lysergic Acid Diethylamide (LSD) in the Central Nervous System Experientia 11272 (1955)

38 Tainter, M. L, \& Buchanan, O H. A Companison of Certain Actions of Demerol and Methadone California Med. 70.35 (1949)

39 Barlow, O W, \& Lewis, J R Toxicity and Addiction Liability of Mependine (Demerol) in Expermental Anmals J Pharmacol \& Exper. Therap. 103147 (1951).

40 Uetsuka, A, \& OKuJima, Y. Increase of the Action of Analgesics by Simultaneous Administration of Other Drugs, particularly of Local Anesthetıcs Chem Abstr 47:7662b (1953).

41 Calesnicki; B, Smith, N H, \& Beutner, R Combined Action of Cardiotoxic Drugs* A Study on the Acute Toxicity of Combined Qumine, Mependine, Pentobarbital, Procame and Procame Amide. J. Pharmacol \& Exper Therap 102138 (1951) 